\title{
ESPIRITUALIDAD DEL SACERDOTE DIOCESANO SECULAR (II)
}

DOI: https://doi.org/10.52039/seminarios.v51i176.717

Autor: Florentino Muñoz Muñoz. Sacerdote. Profesor de Teología en el Seminario Mayor de Cáceres y Vicario Episcopal para el Clero de la diócesis de Coria-Cáceres.

\section{CAPÍTULO QUINTO: NATURALEZA DE LA ESPIRITUALIDAD DEL SACERDOTE DIOCESANO SECULAR (II)}

Teniendo en cuenta lo dicho, nos acercamos a la espiritualidad del Presbítero diocesano secular para desentrañar sus raíces humanas, su fondo bautismal, común a todas las espiritualidades, y su perfil propio.

\section{Dimensión humana de la espiritualidad del Sacerdote}

La Carta a los Hebreos $(5,1)$ subraya claramente la "humanidad" del ministro de Dios: pues procede de los hombres y está al servicio de los hombres, imitando a Jesucristo, "probado en todo igual que nosotros, excepto en el pecado" (Heb 4,15). 
"El don del presbiterado y su ejercicio no es algo que se sobrepone de manera extrínseca a la condición humana y cristiana. Más bien, el presbiterado reclama una determinada personalidad humana equilibrada, correctamente articulada con el ministerio presbiteral ${ }^{1}$.

\section{1. "Crecer como personas para servir como pastores"}

La fe cristiana enseña que no hay más que una perfección del hombre: la plena conformación con Jesús, que "ofrece la más absoluta, genuina y perfecta expresión de humanidad"(PDV 72) ya que es el hombre perfecto $^{2}$. Miremos, pues, a Jesucristo.

Los sacerdotes nos dedicamos a un oficio que, más que ningún otro, facilita y exige a la vez el hecho de ser hombres coherentemente. Ninguna otra profesión reclama tan alto grado de consubstanciación con lo humano como la nuestra (J. L. Ruiz de la Peña). Ni la espiritualidad, ni el desarrollo intelectual, ni la preparación pastoral podrán arraigar con verdad en la persona del sacerdote sin una maduración humana de su persona que es exigida por su condición de pastor.

Juan Pablo II invita a los sacerdotes a cultivar las cualidades humanas que inciden en la pastoral: "amor a la verdad, lealtad, respeto de toda persona, sentido de justicia, fidelidad a la palabra dada, compasión, coherencia, equilibrio" (PDV 43). Además, el ministerio Pastoral ha de estar avalado también por otras cualidades humanas: sencillez, afabilidad, hospitalidad, sinceridad, prudencia, discreción, generosidad, disponibilidad, capacidad de relación fraterna, perdón, consuelo...

${ }^{1}$ Juan Pablo II enseña que "el presbítero, en efecto, llamado a ser imagen viva de Jesucristo Cabeza y Pastor, debe procurar reflejar en sí mismo la perfección humana que brilla en el Hijo de Dios hecho hombre" (PDV 43). Mons. D. Ciriaco Benavente Mateos manifiesta: "El presbítero no es ángel, sino hombre. Nos interesa su humanidad. La gracia del ministerio podría parangonarse, salvadas las distancias, con la de la Encarnación del Verbo. El Hijo de Dios, al hacerse hombre, asumió la condición humana como vehículo de revelación y redención. Su divinidad se expresa y desentraña en su humanidad. Por eso, vamos a tomar en consideración los aspectos humanos de nuestra vida: la salud y la enfermedad, el trabajo y el descanso, la juventud y la ancianidad, la soledad y la compañía, el hábitat y la economía. Todo ello para buscar una existencia grata y saludable a través de la cual se exprese la alegría de quien se siente sanado y salvado por nuestro Señor Jesucristo" (Ib.). K.Rahner: "El sacerdocio cristiano en su realización existencial", Barcelona 1974.

2 Concilio Vaticano II: "Sólo por Cristo y en Cristo se esclarece el misterio del que es portador cada persona", pues "Él revela el hombre al hombre y le muestra la sublimidad de su vocación" (GS 22). 
Ahora bien, el ejercicio del ministerio, realizado con amor, por la vida de la Iglesia y del mundo, es decir, vivido en la caridad pastoral, ha de conducir al sacerdote hacia su plenitud existencial, su realización plena como hombre ya que el amor, vivido en el quehacer diario, es el que va dando forma, el que va configurando a toda la persona humana hacia su plenitud existencial (Fco. J. Díaz Lorite).

Contenidos del crecimiento humano:

- La madurez humana (cf. OT 11) que se manifiesta en "la estabilidad de espíritu, la capacidad para tomar decisiones prudentes, la rectitud en el modo de juzgar sobre los acontecimientos y las personas..." 3 .

- La unidad de vida es fruto de la caridad pastoral en el Presbítero. Cuando no existe la unidad de vida surgen el descontento, el nerviosismo, el olvido de lo esencial. El Sacerdote, sostenido por la gracia del Espíritu, debe mantener y acrecentar la unidad de vida que evitará la dispersión y las dicotomías que hacen estéril e infecundo su ministerio pastoral (cf. PO 14).

- La comprensión humana. El lugar de este crecimiento es el contacto diario con las personas concretas y el compartir con ellas la vida de cada día. "Este roce desde la encarnación", al estilo de Jesús, Verbo Encarnado, es el que abre al Sacerdote a la comprensión (sintonía mental), a la comunión afectiva (sintonía vital) y al compromiso sincero (sintonía práctica) (cf. PDV 72).

- Ser puente y no obstáculo en el encuentro del hombre con Cristo Redentor. Debemos hacer nuestro ministerio creíble y aceptable para que sea puente y no obstáculo en el acercamiento de los hombres a Dios..."

- Ser personas equilibradas Es necesario tener un adecuado equilibrio entre oración y acción, teoría y praxis, sentimientos y palabras, trabajo y descanso, acción y oración... Cuidemos de que no vaya cada cosa por su lado, sino que haya una convergencia e integración.

- Madurar afectivamente desde la centralidad del amor. La madurez afectiva consiste en la capacidad para amar intensamente y para dejarse amar honesta y limpiamente. Amar en el Señor y desde el Señor (cf. PDV 44). El reverso de la madurez afectiva es el "narcisismo".

3 Juan Pablo II afirma que "el crecimiento y la maduración humana del sacerdote realza su servicio pastoral, dándole envergadura y credibilidad, especialmente necesaria en momentos de misión" (PDV 44). 
- Vivir el celibato como expresión de amor a Jesucristo y a la comunidad. La madurez afectiva es "una base firme para vivir la castidad con fidelidad y alegría" (PDV 44). Ahora bien, son también necesarias "la prudencia, la renuncia y la vigilancia".

- Vivir la libertad como don de sí mismo para una auténtica realización personal. El Sacerdote ha decidido en libertad ser "hombre para los demás", y entregarse por entero al servicio del prójimo (PDV 44). El camino de realización propia es el dominio de sí y la entrega al servicio de los demás.

- Educar la conciencia moral como respuesta consciente, libre y amorosa a las exigencias de Dios y de su amor.

- La salud integral de los presbíteros. Se trata de dignificar las condiciones materiales de vida, humanizar la convivencia doméstica y social, actualizar la formación teológica y pastoral, cultivar la vida espiritual. Esto no es un lujo, sino una necesidad primaria de los sacerdotes. El descuido o la insuficiente atención a estas necesidades, perjudica la vida de los presbíteros, crea en ellos una especie de conciencia de desamparo e, incluso, puede paralizar el desarrollo de su vida de fe y sus actividades pastorales.

- Las virtudes humanas que hacen al presbítero digno de la estima de sus hermanos: "bondad de corazón, paciencia, amabilidad, fortaleza de ánimo, amor por la justicia, equilibrio, fidelidad a la palabra dada, coherencia con las obligaciones libremente asumidas, etc." 4 .

\subsection{Dimensión humana en la espiritualidad del Sacerdote}

La espiritualidad del Sacerdote tiene un substrato humano ya que el Sacerdote, como ser humano, es un "espíritu encarnado" (X. Zubiri), ha sido tomado de entre los hombres y está puesto al servicio de la humanidad "en las cosas que se refieren a Dios" (Heb 5,1) 5 . n. 75 .

${ }^{4}$ Congregación para el Clero: "Directorio para el Ministerio y la Vida de los Presbíteros"

5 J. L. Ruiz de la Peña escribe: "el sacerdote ha de ser el hombre que, en su humanidad, descubre las huellas de su nativa propensión a lo divino, más aún, que ve en ella su más relevante seña de identidad. La oración, la conciencia de la religación al misterio del Absoluto, la experiencia de la presencia de Dios, deben ser en él no sólo una exigencia de su ministerio, sino la modalidad cotidiana de realizar su esencia humana, su respiración... La gracia no sobreviene 
Así como la gracia "supone la naturaleza y la perfecciona" de modo semejante la espiritualidad del Sacerdote tiene que ver con la naturaleza humana.

Dios como el "interior intimo meo" es la primera etapa de mi itinerario hacia Él; tal es la "religiosidad esencial" (K.Rahner), la del orden de la creación. Yo soy criatura de Dios; Él es mi origen y mi fin; y entre el origen y el fin, Dios es quien me sustenta permanentemente en la existencia. Saltarse este orden de la creación para instalarse en el siguiente (el orden de la gracia sobrenatural) entraña el riesgo cierto y grave de que dicha elevación sobrenatural aparezca como superestructura sobrevenida desde fuera y, por tanto, no afectante a mi ser" (J. L. Ruiz de la Peña).

\section{El fondo bautismal de la espiritualidad del Sacerdote}

Toda espiritualidad cristiana, también la del Presbítero, tiene un fondo bautismal común a otras espiritualidades, ya que los sacerdotes recibieron "ya en el consagración del Bautismo, como todos los fieles en Cristo el signo y el don de una gran vocación y gracia (PO 12). Por eso todo lo que se exige al sacerdote para alcanzar la perfección evangélica como ministro que actúa "en la persona de Cristo" tiene su fundamento y su raíz en el sacramento del Bautismo, por el que los hombres incorporados al cuerpo de Cristo, quedan destinados por el carácter bautismal al culto del Padre "en el Espíritu y la verdad" (Jn 4,23-24). También para el sacerdote el Bautismo es "el fundamento de la existencia cristiana".

\section{1. ¿En qué consiste este fondo bautismal?}

Por el Bautismo, sacramento de la Iniciación Cristiana, somos incorporados al misterio de la muerte y de la resurrección de Cristo ( $\mathrm{Rm}$ 6,111) y a la Iglesia, somos llamados a la santidad y somos enviados al

a la naturaleza como un meteorito epidérmicamente adosado a ella, sino como aquello que la cumple y la colma porque responde a su más acendrado y hondo dinamismo" ("Condición humana y ministerio ordenado", en "La formación humana de los Sacerdotes según Pastores dabo vobis", Comisión Episcopal del Clero; 1994). 
mundo a ser testigos del Señor con la fuerza del Espíritu Santo para vivir en santidad, amor y justicia.

El Bautismo es el sacramento que libera al hombre del poder de las tinieblas borrando el pecado original, y hace pasar a los hombres de la condición humana en la que nacen como hijos de Adán al estado de los hijos adoptivos de Dios, haciéndolos nuevas criaturas, miembros del cuerpo de Cristo, e incorporándolos a la Iglesia ${ }^{6}$.

Desentrañemos esta síntesis del Bautismo.

\section{A) La inserción del bautizado en el misterio de Jesucristo}

Por el Bautismo somos injertados en el misterio de Jesucristo, Hijo de Dios y Cabeza de la nueva humanidad. Recordemos las enseñanzas de San Pablo: "Los que por el Bautismo nos incorporamos a Cristo, fuimos incorporados a su muerte. Por el Bautismo fuimos sepultados con Él en su muerte, para que así, como Cristo fue despertado de entre los muertos por la gloria del Padre, así también nosotros andemos en una vida nueva. Porque si nuestra existencia está unida a Él en una muerte como la suya, lo estará también en una resurrección como la suya... El bautizado es sepultado con Cristo, muriendo al hombre viejo, para resucitar a una nueva vida, la vida del Espíritu (cf. Rm 6,3-6) 7 .

Esta inserción del bautizado en el misterio de Cristo es tan profunda que produce en él efectos extraordinarios. En efecto, "por el santo bautismo somos hechos hijos de Dios en su Unigénito Hijo, Cristo Jesús... Se cumple así en la historia de cada uno el eterno designio del Padre: "a los que de antemano conoció, también los predestinó a reproducir la imagen de su Hijo, para que Él fuera el primogénito entre muchos hermanos" (cf. Rm 8,29) (ChFL 11).

El Bautismo al "insertar a los hombres en el ser divino de Cristo, hace "santos" a todos los bautizados (cf. Rm 1,7). Esto lleva consigo la

${ }^{6}$ Catecismo de la Iglesia Católica, n.1213.

${ }^{7}$ Olegario González de Cardedal: "El bautismo nos inserta en el destino mismo de Cristo, de forma que quien se sumerge en el baño de la regeneración desciende con Cristo a su muerte y asciende con Él a la vida nueva, que anticipa la resurrección futura. El sentido primordial del bautismo es la conmutación de destino entre el bautizando y Cristo: bautizarse es asumir el ser y el existir de Cristo como referencia propia de origen, forma de hacer y actitud ante el futuro" ("La Entraña del Cristianismo", p.855). 
obligación moral de obrar como Cristo en la obediencia filial al Padre (cf. IPe 1,15-16).

El Presbítero ha sido llamado, como también los demás bautizados, a "conformarse" con Cristo $(\mathrm{Rm} 8,29)$ y a hacer suya la experiencia de Pablo: "vivo yo, pero no soy yo, es Cristo quien vive en mî" (Gál 2,20). El Padre reconoce en cada bautizado los rasgos de su Hijo Amado y "ama en nosotros lo que amaba en él" (Misal Romano, pref. VII dominical del T. Ordinario). "El bautizado es hijo de Dios en el Hijo Jesucristo, de manera que Él es el "Primogénito de muchos hermanos" (Rm 8,29).

Al recibir el Bautismo los bautizados se comprometen a seguir a Jesucristo. Este seguimiento de Jesús implica:

* estar con Él -dimensión mística-,

* vivir en fraternidad -dimensión comunitaria-,

* ser enviados en misión -dimensión misionera-,

* expulsar a los demonios -dimensión mesiánica-,

* defender la naturaleza -dimensión ecológica-.

El Bautizado recibe en el Bautismo la unción del Espíritu Santo. Con esta unción espiritual, el cristiano puede, a su modo, repetir las palabras de Jesús: "El Espíritu del Señor está sobre mí: por lo cual me ha ungido para evangelizar a los pobres, me ha enviado a proclamar la liberación a los cautivos y la vista a los ciegos, a poner en libertad a lo oprimidos, y a proclamar el año de gracia del Señor" (Lc.4,18-19).

B) La incorporación del bautizado en la Iglesia

El sacramento del Bautismo además nos incorpora a la Iglesia,. En el Bautismo ha nacido y renace el nuevo Pueblo de Dios que transciende los límites humanos de raza, lengua, cultura, nación... para formar un solo Cuerpo porque "todos nosotros hemos sido bautizados en solo Espíritu" (ICor 12,13).

El Espíritu Santo concede a cada bautizado sus dones y carismas para común utilidad y para la edificación del Cuerpo de Cristo. (cf. ICor 12,1-11; Ef 4,7-13). Cada miembro de la Iglesia al participar de la dignidad profética, sacerdotal y real de Cristo, común a todos los fieles cristianos, está llamado a colaborar en la misión salvífica de la Iglesia. 


\subsection{La espiritualidad que nace y brota del Bautismo}

Juan Pablo II enseña que el Bautismo es "fundamento de la existencia cristiana" (TMA 41). Esto quiere decir que "toda nuestra vida ha de estar impregnada de la conciencia de ser hijos de Dios en el Hijo Jesucristo; una conciencia agradecida, gozosa, testimonial. A esto es a lo que se llama espiritualidad bautismal cuyos rasgos más importantes vamos a exponer inspirándonos en las reflexiones de Mons. Julián López 8:

* aceptar como nuestro el destino que el Padre entregó a Jesús y elegir como nuestra la forma de vida -la obediencia y el servicio- que eligió Jesús, confiando en que el Padre responderá con nosotros como respondió con Él,

* vivir la alegría de llamarnos y ser en verdad hijos de Dios (IJn 3,1),

* poder invocar a Dios con el nombre de "Padre" (cf. Rm 8,15-16),

* confesar a Jesucristo como "Señor" (cf. ICor 12,3),

* vivir en y con Jesucristo, guiados por el Espíritu Santo,

* orar con la confianza de los hijos (Mat 6,6-13) y en el nombre de Jesús (cf. Jn 14,13s),

* dejarse guiar por el Espíritu que fortalece nuestra debilidad (cf. Rm 8,26-27) y ora en nosotros ( $\mathrm{Rm} 8,26-27)$,

* hacer nuestros los sentimientos de Cristo (Fil 2,5): fidelidad, servicio, donación de sí, entrega al servicio del Reino....

* celebrar el Año Litúrgico como camino de espiritualidad e itinerario pastoral.

\section{El perfil de la espiritualidad del Sacerdote diocesano secular}

Después de haber presentado el "fondo bautismal" de la espiritualidad del Sacerdote, común a todas las espiritualidades cristianas, mostramos a continuación el "perfil propio" de esta espiritualidad.

${ }^{8}$ Mons. Julián López: "Jesucristo nuestro Salvador en la iniciación cristiana y en la vida de la fe" (Exhortación pastoral, 1996; nn.18-19). 


\subsection{Enseñanzas del Magisterio de la Iglesia}

$\mathrm{Al}$ abordar este tema tan importante y fundamental nos ha parecido oportuno y necesario partir del Magisterio de la Iglesia. Sus enseñanzas serán las que nos guíen en nuestras reflexiones ${ }^{9}$.

3.2. Los contenidos básicos de la espiritualidad específica del Sacerdote diocesano

Para mayor claridad, expondremos primero de la espiritualidad del sacerdote y, después, la del sacerdote diocesano.

A) La espiritualidad del Sacerdote:

* No es algo sobreañadido al Sacerdote, ni es un programa de actuaciones, sino que procede de la constitución interna del ser y de la línea fundamental de la misión del sacerdote.

* Consiste en la forma peculiar de encarnar la vida según el Espíritu, común a todos los bautizados, en su especial vocación y misión en el seno de la Iglesia y al servicio de la sociedad.

* Está matizada por unas realidades de gracia peculiares: la consagración por el carácter, el seguimiento de Jesús al estilo de los Apóstoles, la comunión eclesial y la misión que prolonga la misión de Cristo.

* Tiene estas características:

- Seguimiento evangélico concretizado en los "consejos evangélicos".

- Santificación en el ejercicio de los ministerios.

- El servicio sin privilegios ni ventajas humanas (PO 1 y 13).

- La eucaristía como "fuente y culmen de toda la evangelización" (PO 5).

- La docilidad a la acción del Espíritu Santo (PO 2).

- Una actitud mariana (PO 18).

${ }^{9}$ Los principales documentos del Magisterio de la Iglesia sobre la espiritualidad específica del Sacerdote son los siguientes:

- Juan Pablo II: "Pastores dabo vobis" n. 20.

- Congregación para la evangelización de los Pueblos: "Guía pastoral para los sacerdotes diocesanos de las Iglesias que dependen de la Congregación para la evangelización de los Pueblos" (Roma, junio de 1989). 
- Sentido pastoral de las virtudes teologales y cardinales (PO 15-17).

- Formación permanente integral del sacerdote (PO 19).

- Transparencia de Cristo Sacerdote y Buen Pastor.

B) La espiritualidad del Sacerdote diocesano secular.

Esta espiritualidad está constituida por las mismas realidades de gracia, referidas anteriormente, pero matizadas por la caridad pastoral como configuración con Cristo Cabeza, Pastor, Esposo y Servidor de la Iglesia, la cual, a su vez, queda matizada por:

* La pertenencia a la Iglesia diocesana mediante la incardinación o compromiso de servicio que incluye la corresponsabilidad en la misión universal.

* La unión con el propio Obispo en la pastoral y en la espiritualidad.

* La pertenencia al Presbiterio diocesano de modo estable.

* El ser principio de unidad (en unión con el obispo) respecto a los carismas, vocaciones y ministerios existentes en la comunidad eclesial.

* Ayudar a la comunidad a vivir y actuar en conformidad con sus raíces apostólicas en relación con el Obispo que la preside como sucesor de los Apóstoles ${ }^{10}$.

10 Congregación para el Clero manifiesta que "el sacerdocio ministerial, en la medida en que configura con el ser y el obrar sacerdotal de Cristo, introduce una novedad en la vida espiritual de quien ha recibido este don. Es una vida espiritual conformada por la participación en la capitalidad de Cristo en su Iglesia, y que madura en el servicio ministerial a ella: una santidad en el ministerio y para el ministerio" ("El Presbítero, pastor y guía de la Comunidad Parroquial", n.12). Congregación para el Clero pone de relieve que "la profundización en la conciencia de ser ministro (PDV 25) es, por tanto, de gran importancia para la vida espiritual del sacerdote y para la eficacia de su ministerio mismo" (ib. n.13). 


\section{CAPÍTULO SEXTO: LAS CLAVES DE LA ESPIRITUALIDAD DEL SACERDOTE}

Las claves concretas de la espiritualidad del Sacerdote diocesano secular son la sacramentalidad, la relacionalidad y la ministerialidad. Por su importancia, las exponemos a continuación.

\section{La espiritualidad del Sacerdote desde la sacramentalidad}

\section{Introducción: la sacramentalidad}

Nuestra sociedad actual se ha secularizado y es por tendencia materialista, por lo que es poco sensible al simbolismo. Por ello, le resulta difícil aceptar "la encarnación del Hijo de Dios y la sacramentalidad"

En este contexto, los sacerdotes renovarán la comprensión teológica de "la sacramentalidad y del Sacerdocio Ministerial", cuidarán el decoro y el aspecto sagrado de la celebración litúrgica y ayudarán a los fieles a participar activa, consciente y fructuosamente en la celebración de los sacramentos, especialmente en la Eucaristía.

La sacramentalidad es una clave muy importante en la espiritualidad del Sacerdote ya que constituye la referencia básica para comprender su identidad, su ministerio y su vida, y para radicar en ella la configuración de su espiritualidad y de sus relaciones 1 .

La sacramentalidad abarca los signos sacramentales, la acción pastoral en su totalidad y el ser mismo del sacerdote. Esta estructura sacramental, en las personas y en las obras pastorales, está en estrecha relación con la humanidad de Cristo ya que la prolonga análogamente.

${ }^{1}$ Mons. Julián López: "La raíz sacramental confiere una dimensión especifica a toda la existencia del sacerdote y, en consecuencia, debe encontrar su traducción en la espiritualidad, es decir, en la vida y en el ministerio de quien, siendo hijo de Dios en el Hijo Jesucristo bajo la acción del Espíritu Santo, ha sido también configurado a Cristo Cabeza y Buen Pastor. Como discípulo de Jesús, el sacerdote es llamado a la perfección según el modelo del Padre celestial" (cf. Mat.5,48) en razón de la participación en el misterio pascual de Jesucristo como todos los bautizados y confirmados, y en razón de la participación en la consagración y misión de Aquel a quien ha de representar en la asamblea de los fieles" ("Espiritualidad litúrgica y sacramental", en "La formación del Sacerdote del tercer milenio", Arzobispado de Sevilla, p.249). 


\subsection{La sacramentalidad del ministerio}

Jesucristo es el mediador entre Dios y los hombres (I Tim 2,5). La mediación de Cristo nos hace posible recibir la plenitud del amor de Dios y alcanzar la caridad universal con los demás. Ahora bien esta mediación de Cristo tiene que manifestarse visiblemente para que pueda funcionar en la vida cristiana. Esto acontece en el ministerio del sacerdote. De esta manera todo creyente pueda acoger la mediación de Cristo y recibir así el amor divino, necesario para la transformación del mundo.

¿En qué consiste la sacramentalidad del ministerio?

La sacramentalidad del ministerio es el rasgo más específico de la identidad del presbítero ${ }^{2}$. Sacramentalidad significa aquí "estructura de encarnación" que significa: la acción salvadora de Cristo-Jesús encarnada en el ministerio del Sacerdote, y el dinamismo pneumático y la vivificación "espiritual" de este ministerio.

La sacramentalidad del ministerio está enraizada en la sacramentalidad de la Iglesia, ya que la Iglesia es "misterio de comunión y de relacionalidad a imagen de la Stma. Trinidad", "sacramento de Jesucristo" (LG 1), sacramento universal de salvación" (AG 1), "Iglesia teándrica" (LG 8) a la que Cristo ha enriquecido con el ministerio apostólico (LG 19-20) y el Espíritu la llena de dones y carismas (LG 4). Esta radicación eclesiológica del ministerio nos dice cuál es su lugar matricial y nos remite a una vivencia eclesial del mismo.

La sacramentalidad del ministerio nos descubre su originariedad cristológica, nos lo muestra como don inmerecido del Espíritu y nos enseña que el ejercicio del ministerio no es pura función ni mera burocracia, sino que es "servicio del Espíritu" (IICor 2,8).

Los sacerdotes han de cuidar con sumo interés la presencia y la cercanía, la transparencia de vida, los gestos verdaderamente significativos, la publicidad de los ministros y de sus acciones, las realización de éstas en campos de misión ya que son aspectos que influyen directamente en que los signos personales y pastorales puedan llegar a sus destinatarios.

${ }^{2}$ A. Vanhoye:"Sacramentalidad del Ministerio", en "Espiritualidad del Presbítero diocesano secular"; Simposio. Comisión Episcopal del Clero, EDICE,1987; pp.71-85. 


\subsection{La sacramentalidad de la persona ordenada}

Al hablar aquí de la sacramentalidad de la persona ordenada, se quiere decir lo siguiente: "la ordenación afecta también a la persona misma del sujeto ordenado y caracteriza su existencia. Es el inicio determinante de toda una historia vital" 3.

El sacerdote es ordenado para representar al Señor glorioso como Cabeza y santificador de todo su cuerpo eclesial en el culto de la Nueva Alianza y en la obra de la salvación humana ${ }^{4}$.

Dicho de otro modo, por su ordenación, el Presbítero es constituido sacramento de Jesucristo mediador en la comunidad eclesial y actúa "en la persona de Cristo". El sacerdote "representa" sacramental y ministerialmente a Jesucristo, actúa "en persona de Cristo Cabeza" (PO 2) y "presencializa sacramentalmente al único Sacerdote Jesucristo". Desde su ser y actuar sacramentaliza, manifiesta, actualiza, el sacerdocio, la capitalidad, el pastoreo y el servicio de Cristo en la Iglesia y para el mundo con la fuerza del Espíritu Santo que es el que consagra y envía.

Ahora bien, tengamos presente que no hay más que un solo Mediador, el Hombre Cristo Jesús, y es Él mismo quien actualiza por su Espíritu la redención realizada en la Cruz. Los Sacerdotes no suplen a Jesús ni lo sustituyen; los Sacerdotes nada pueden añadir a lo que constituye formalmente el acto sacerdotal de Cristo. Su ministerio no podrá ser más que un servicio al despliegue del "efapax" del único sacrificio del único Sacerdote de la Nueva y Eterna Alianza.

\section{Consecuencias}

La condición de signo personal de Cristo en la asamblea de los fieles pide al sacerdote una especial relación con Aquel a quien representa y

${ }^{3}$ Santiago del Cura Elena: El sacerdote es, por tanto, sacramento vivo de Cristo en medio de su Iglesia, especialmente en la acción litúrgica, en orden a la perfecta glorificación de Dios y a la santificación del hombre (cf. SC 7; 10)"

${ }^{4}$ Mons. J. López: "El sacerdote es, por tanto, sacramento vivo de Cristo en medio de su Iglesia, especialmente en la acción litúrgica, en orden a la perfecta glorificación de Dios y a la santificación del hombre (cf. SC 7; 10) ("Espiritualidad litúrgica y sacramental", en "La formación del sacerdote del tercer milenio", Arzobispado de Sevilla, 2000; p. 251). 
con la misma comunidad eclesial para la que es signo personal del Señor. Esta relación, en términos de espiritualidad sacerdotal ha de traducirse en un ejercicio consciente y digno del ministerio, en particular del ministerio de la presidencia de la celebración eucarística, aspecto que unifica y da sentido a toda la existencia del sacerdote, dada la centralidad de la Eucaristía en la vida de la Iglesia (Mons. J. López).

Los sacerdotes no han de considerar lo visible, factible, planificable y revisable como la única realidad en la acción pastoral, sino que han de reconocer también la acción del Espíritu de Dios en ella y por ella (cf. EN 75).

Las acciones pastorales de los sacerdotes ni suceden, ni se suman a la mediación del único Mediador, sino que son acciones sacramentales ya que a través de ellas Cristo sigue ejerciendo su sacerdocio (cf. PDV 25) con la fuerza del Espíritu Santo.

Los Sacerdotes han de "ocultarse" para que en su acción se haga visible y actúe el Señor. La práctica de tal disponibilidad absoluta en el ejercicio del ministerio le va identificando cada vez más profundamente con Él (J. Perea).

Los Sacerdotes han de tener una espiritualidad de amor y de gratitud que les haga cada vez más conscientes de que su sacerdocio y ministerio es un don y regalo de Dios para la Iglesia y para la humanidad.

\section{La espiritualidad del Sacerdote desde la relacionalidad}

\section{Introducción: el ser y el ministerio del Sacerdote son relacionales}

Los Sacerdotes han de potenciar la dimensión comunional y relacional implicada en su propia naturaleza humana y exigida por el sacramento del Orden que han recibido. La relacionalidad, por tanto, no es algo exigido desde fuera por una norma o una ley, sino que está postulada por su propia condición humana, cristiana y sacerdotal.

Los Sacerdotes, por tanto, han de evitar en ellos mismos todo signo de individualismo, insolidaridad, aislamiento, egocentrismo y han de omitir cualquier actitud o comportamiento que generen exclusión, marginación, rechazo, olvido, desprecio de alguien....

El Sacerdote es una persona eminentemente relacional, "hombre de comunión", y, por tanto, debe tener capacidad de relacionarse (cf. PDV 
43). Por ser el ministerio del Presbítero comunional, su identidad es esencialmente relacional y su actitud de comunión ha de mostrarse y ejercitarse en cada una de sus relaciones 5 .

Las relaciones del Presbítero nacen y brotan del sacramento del Orden, por lo que son sacramentales y no sólo exigencias morales de coherencia o de cumplimiento. En este sentido, sacramentalidad y relacionalidad están íntimamente unidas ${ }^{6}$.

Por tanto, es necesario que el Sacerdote cultive todas y cada una de sus relaciones para que quede siempre salvaguardada su identidad y fisonomía y espiritualidad y misión 7.

Adentrémonos en el complejo mundo de las relaciones del Presbítero.

\section{Las relaciones del Sacerdote}

El Presbítero tiene unas relaciones fundantes que son las que le capacitan para ser luego competente relacionalmente. Ahí conduce el itinerario espiritual con el fin de asentar bien la relacionalidad presbiteral. Veamos estas relaciones.

\subsection{Relación del Sacerdote con Jesucristo, Cabeza y Pastor de la Iglesia}

Por el sacramento del Orden los Presbíteros "quedan sellados con un carácter particular, y así se configuran con Cristo Sacerdote, de suerte que

5 Juan Pablo II dice a este respecto: "No se puede definir la naturaleza y la misión del sacerdocio ministerial si no es bajo este múltiple y rico conjunto de relaciones que brotan de la Stma. Trinidad y se prolongan en la comunión de la Iglesia, como signo e instrumento, en Cristo, de la unión con Dios y de la unidad de todo el género humano" (PDV 12).

${ }^{6}$ Mons. D. Ciriaco Benavente manifiesta en esta misma dirección: "cultivar sólo la dimensión cristológica puede hacer de nosotros presbíteros autocráticos; atender sólo a la dimensión eclesiológica podría llevarnos a sentirnos no más que delegados de la base; olvidar el presbiterio alentaría el individualismo; fomentar sólo la dimensión de servicio, el funcionalismo" ( ib.)

${ }^{7}$ Mons. D. Ciriaco Benavente pone de manifiesto la fuente de donde dimanan estas relaciones del Presbítero: "El sacramento del Orden introduce al Sacerdote en una red de relaciones constitutivas de su identidad. Todas y cada una de estas relaciones introducen en nuestra existencia un dinamismo excéntrico, nos hace expropiados para utilidad pública. La manera cómo se viven y se articulan, dan el rostro peculiar e inconfundible del pastor" (ib.). 
puedan obrar como en la persona de Cristo Cabeza" (PO 2), no solo en la Eucaristía (LG 28) sino también, aun con menos intensidad que los Obispos, en la triple función de enseñar, santificar y de dirección (PO 2). " La referencia a Cristo es la clave absolutamente necesaria para la comprensión de las realidades sacerdotales" (PDV 12). Esta relación con Cristo es prioritaria, fontal y originaria de donde dimanan las demás referencias del "ser" y "actuar" del Sacerdote; además debe ser entendida en la línea de la sacramentalidad (cf. PDV 15).

Esta configuración con Cristo es un proceso inacabado de apropiación personal y existencial, donde vamos deviniendo aquello que somos, donde vamos asimilando de modo gradual el modo de vivir y de comportarse de Jesús durante su ministerio público: "existe un vínculo profundo entre ministerio y existencia" (K. Rahner), es decir, debe crearse una íntima relación entre "representar a Cristo" e "ir transformándose en Jesús".

Toda la persona del presbítero debe ir orientándose hacia Jesús de Nazaret, que es el modelo del Sacerdote. Recuperemos, pues, "la forma de Jesús". La fuerza del Espíritu Santo va "convirtiendo en existencialmente sacerdote a aquel que ya lo es sacramentalmente por la ordenación" (C. Episc. del Clero: "Espiritualidad sacerdotal y ministerio"). Pasemos, pues, de la configuración ontológica con Cristo a la configuración existencial con Él. La espiritualidad del Sacerdote le exige estar cerca de Jesús, amarle y tener un trato personal con Él 8 .

Se trata, por tanto, de que el Sacerdote "entrañe" en sí mismo la imagen histórica de Jesús de Nazaret y la imagen viviente de Cristo resucitado para así poder actuar en el Pueblo de Dios y en medio de sus comunidades "en persona de Cristo" de verdad. Sería bueno que los Presbíteros se encuentren con Cristo mediante la experiencia de Emaús (cf. Lc 24,13-35).

¿Qué nos exige esta configuración existencial con Cristo?

Representar a Cristo en la Comunidad Cristiana exige al Sacerdote estar con Cristo, escuchando sus palabras, viendo sus signos para descifrar su misterio, el misterio de su Persona y del Reino. Estar con Él hasta entrar en comunión ilimitada de destino. Estar con Él para ser modelado

${ }^{8}$ Elías Royón: "Dejemos, pues, nuestras vidas junto a la vida de Jesús para que se vaya convirtiendo; dejemos nuestras personas, transformadas objetivamente en el sacramento del Orden, junto al Buen Pastor, para que se vayan transformando subjetivamente" ("Oración y experiencia de Dios en la vida del Sacerdote", en "Espiritualidad Sacerdotal", Congreso, p.377; Comisión Episcopal del Clero; 1989). 
y moldeado por Él. No sólo hay que estar con Él; es necesario también existir en Jesús como dirá Pablo: “vivo yo, pero no soy yo quien vivo; es Cristo quien vive en mí” (Gál 2,20). Hay que vivir en continua comunión y comunicación con Él.

Representar a Cristo con autoridad evangélica sólo se puede hacer siendo signos vivos de Cristo, Cabeza y Pastor, que amó a la Iglesia y se entregó por ella sin medida, hasta dar la vida por ella. "Amar a la Iglesia y entregarse a ella en el servicio ministerial requiere amar profundamente al Señor Jesús".

\section{La relación del Sacerdote con el Padre y el Espíritu Santo}

\section{Relación con el Padre}

Por medio de Cristo, el Presbítero se relaciona con el Padre. El Presbítero no es padre, sino presencia sacramental del Padre. Hace presente en la Iglesia la paternidad de Dios como "oferta gratuita de salvación desde el designio de Dios realizado en Cristo Jesús, Hijo y Enviado del Padre". Y la paternidad de Dios se representa con el mismo estilo que la encarnó Jesús: la autoridad se entiende y se ejerce desde el servicio, la dedicación y la entrega, es decir: "lavando los pies a los discípulos". El Presbítero es "imagen del Padre" que prepara a sus hijos el alimento cada día. "Ejerciendo, en la medida de su autoridad, el oficio de Cristo Cabeza y Pastor, reúnen la familia de Dios como una fraternidad, animada con espíritu de unidad, y la conducen a Dios Padre por medio de Cristo en el Espíritu" (LG 28). El Sacerdote es "icono de la misericordia del Padre" para todos.

\section{Relación con el Espíritu Santo}

Por medio de Cristo, el Presbítero se relaciona con el Espíritu Santo, Maestro de la Verdad viva 9. El ministerio de los sacerdotes es un "ministerio del Espíritu" (IICor 3,8) ya que el anuncio de la Palabra (cf. DV 5),

9 Juan Pablo II manifiesta que "mediante la unción sacramental del Orden, el Espíritu Santo configura a los ministros ordenados con un nuevo título y específico a Jesucristo Cabeza y Pastor, los conforma y anima con su caridad pastoral y los pone en la Iglesia como servidores autorizados del anuncio del Evangelio a toda criatura y como servidores de la plenitud de la vida cristiana de los bautizados" (PDV 15). 
la santificación de los fieles (cf. LG 4), el servicio a la unidad del Pueblo de Dios (LG 4) exigen al Presbítero estar en comunión con el Espíritu Santo. Porque el Espíritu Santo ha configurado con Cristo al Sacerdote, éste ha de ser un "hombre del Espíritu", una persona espiritual, un hombre de Dios, con experiencia de oración, con la sabiduría que Dios comunica a sus elegidos. Con la fuerza del Espíritu, el sacerdote sabrá ejercer el discernimiento personal y comunitario para reconocer los dones, carismas y ministerios que el mismo Espíritu está regalando continuamente a la Iglesia, y puede vivir el celibato como un don por el Reino, la obediencia como corresponsabilidad con su Obispo, la pobreza como libertad para ser voz y defensa de los pobres, viviendo como ellos (J. A. González Montoto).

El Presbítero debe ser hombre del Espíritu que tenga un gran corazón para no perder la alegría ante las dificultades; que no se sienta humillado por los fracasos en la evangelización, ni envanecido por sus éxitos. Con la fuerza del Espíritu seguirá proponiendo el Evangelio con libertad y confianza, vivirá en la esperanza de que el futuro nos lo regala Dios porque es suyo, no nuestro. Sabe que no pertenece a una Iglesia acabada, ya que hay muchas formas de vida en ella. Sabe que la Iglesia no comienza ni termina con sus esfuerzos. Sabe que sus esfuerzos no son los únicos, ni con él comenzaron ni con él han de terminar esos esfuerzos.

\section{El Sacerdote, hombre de la Trinidad}

El sacerdote, como prolongación visible y signo sacramental de Cristo..., se encuentra insertado en el dinamismo trinitario con una particular responsabilidad (Directorio... n.4). La espiritualidad del Sacerdote tiene una dimensión trinitaria, ya que la identidad del sacerdote tiene su fuente última en el misterio de la Stma. Trinidad (PDV 12). En efecto, el Sacerdote ha de alabar a Dios Padre por Cristo en el Espíritu Santo y ha de "glorificar a la Stma. Trinidad de la que todo procede y a la que todo se dirige, en el mundo y en la historia" 10 ha de mantener un trato familiar y asiduo con el Padre por el Hijo en el Espíritu Santo por medio de la adoración, la oración, la obediencia y la confianza; y ha de encaminarse a la consumación final en el misterio inefable de Dios Padre, Hijo y Espíritu

\footnotetext{
10 Juan Pablo II: "Tertio Millennio adveniente", n.55.
} 
Santo. Juan Pablo II invita a todos los sacerdotes a que "toméis conciencia más seria de las raíces teologales de vuestro ministerio presbiteral. Para que el mundo crea, los sacerdotes tienen que ser hoy más que nunca "hombres de la Trinidad"11 y han de vivir las relaciones con la Trinidad"2.

\subsection{Relación del Sacerdote con la Iglesia Particular}

En la Iglesia Particular o Diócesis -"porción del Pueblo de Dios que se confía a un Obispo para que la apaciente con la cooperación del presbiterio"- "se encuentra y opera verdaderamente la Iglesia de Cristo, una, santa, católica, y apostólica" (ChD 11). Por eso afirmamos que la Iglesia Particular es una Comunidad Eclesial completa al servicio del Reino de Dios en un lugar determinado, con todos los elementos que integran y constituyen la Iglesia del Señor: la Palabra de Dios, el Espíritu Santo (LG 7), la Eucaristía (PO 5), el Ministerio Apostólico que subsiste en el ministerio ordenado (LG 20), la Oración comunitaria (SC 7). Esta Iglesia realiza la misión que el Señor le ha confiado: "id al mundo y proclamad el Evangelio..." (Mc16,15).

De la fundamental unión-comunión con Cristo y con la Trinidad deriva, para el presbítero, su comunión-relación con la Iglesia en sus aspectos de misterio y de comunidad eclesial (cf LG 8). La relación del sacerdote con la Iglesia se inscribe en la única y misma relación del sacerdote con Cristo, en el sentido de que la representación sacramental de Cristo es la que instaura y anima la relación del sacerdote con la Iglesia (PDV 21). En efecto, Cristo, como prueba de confianza, le entrega la Iglesia para que la ame, la cuide, la nutra como hizo Él.

En la Iglesia, por tanto, el presbítero representa el amor de Cristo Esposo, y cumple su tarea entregándose a ella con la misma generosidad que su Señor (cf. PDV 22). No se trata de relaciones simplemente cercanas entre sí, sino unidas interiormente en una especie de mutua inmanencia. No se puede separar la fidelidad para con Cristo de la fidelidad para con la Iglesia. La referencia del Sacerdote a la Iglesia parte del hecho

11 St. Tomás de Aquino: "Comentario In IV Sent. Dist.19,q.1, art.1".

12 Juan Pablo II afirma lo siguiente: "No se puede definir la naturaleza y la misión del sacerdocio ministerial si no es desde este multiforme y rico entramado de relaciones que brotan de la Stma. Trinidad y se prolongan en la comunión de la Iglesia, como signo, en Cristo, de la unión con Dios y de la unidad de todo el género humano" (PDV 12). 
mismo de la ordenación, por lo cual el sacerdote se convierte en un signo elocuente del amor y entrega de Cristo por la Iglesia (cf. Ef 5,25). La relación es, por tanto, sacramental.

El Sacerdote es "sacramento de Cristo" por la fuerza del Espíritu Santo al servicio de la Iglesia. Por eso, "la referencia a la Iglesia es necesaria, aunque no prioritaria, en la definición de la identidad del presbítero" (PDV 12).

La dedicación y el servicio del presbítero diocesano a la Iglesia se realiza y se concreta en su pertenencia a una Iglesia Particular con la que se vincula por la ordenación, que incardina al presbítero diocesano en su diócesis de tal modo que "el Presbítero encuentra en su pertenencia y dedicación a la Iglesia Particular, una fuente de significados, de criterios de discernimiento y de acción que configuran tanto su misión pastoral como su vida espiritual" (PDV 31). Para funcionar en plenitud, el presbítero debe vivir una incardinación real y gozosa en la Iglesia. En ella se vive y desde ella se trabaja no porque sea una sociedad moral, cultural o espiritualmente mejor, sino porque en ella, a través de su humanidad, pobre o gloriosa, perdura la realidad viviente de Jesucristo. Se repite aquí lo que es la estructura fundamental del Cristianismo: su condición encarnada. Tengamos presente que la incardinación constituye no sólo un elemento jurídico sino también un valor espiritual con consecuencias pastorales.

El Sacerdote aparece en la estructura de la Iglesia como signo de la prioridad absoluta y de la gratuidad de la gracia que Cristo resucitado ha dado a su Iglesia, y se sitúa no sólo en la Iglesia y sino también al frente de la Iglesia (PDV 16). El Sacerdote ejerce su ministerio en la tensión permanente de estas preposiciones: "con","al frente de" y "para". Aquella indica la fraternidad con los demás cristianos, la segunda expresa la autoridad recibida del Señor y la última pone de relieve el servicio a que está destinado ${ }^{13}$.

Por todo ello, es necesario situar el ministerio de los Presbíteros en el seno y al servicio de la Comunidad eclesial, y también en referencia a los organismos de comunión y de participación de la Iglesia que son lugares en los que el Pueblo de Dios en sus diferentes miembros es convoca-

13 Mons. Ricardo Blázquez: "La relación del Presbítero con la Comunidad", en "La Espiritualidad del Presbítero diocesano secular", Simposio. Comisión Episcopal del Clero,1987; pp.328-329. 
do a ejercer su tarea. Para los Sacerdotes estos organismos son lugares en los que descubren una modalidad comunitaria y sinodal del ejercicio de su ministerio.

¿Cómo ha de vivir el Presbítero su diocesaneidad:

a) Conociendo con ojos de fe a su propia Diócesis: su historia, su geografía, sus gentes, sus necesidades, sus sacerdotes, sus agentes de pastoral, sus Comunidades Religiosas, sus problemas.

b) Amando a la Diócesis. El sacerdote está llamado a ser imagen viva de Jesucristo Esposo de la Iglesia... y a revivir en su vida espiritual el amor de Cristo Esposo con la Iglesia esposa... Ha de ser testigo del amor de Cristo como Esposo y por eso ser capaz de amar a la gente con un corazón nuevo, grande y puro, con auténtica renuncia de sí mismo, con entrega total, continua y fiel, y a la vez con una especie de "celo" divino, con una ternura que incluso asume matices del cariño materno.

c) Potenciando su pertenencia integral a la Iglesia Particular, en la que "encuentra una fuente de significados, de criterios de discernimiento y de acción, que configuran su misión pastoral y su vida espiritual" (PDV $31)$.

d) Respetando la herencia apostólica y la historia de gracia que existen en la Iglesia Particular y colaborando en la misión universal de la Iglesia (LG 28; PO 10; PDV 16-17; 31-32;74).

e) Recobrando la confianza teologal en la Iglesia.

f) Dejándose estimular por los testigos de santidad que en ella han fructificado, dedicándose en cuerpo y alma al cuidado pastoral de la misma.

g) Asumiendo lealmente las orientaciones del propio Obispo que es el sacramento de la unidad de todos los presbíteros diocesanos y la garantía de la legitimidad apostólica de su presbiterio. "Os conviene correr a una con el sentir de vuestro obispo, que es justamente lo que hacéis" (S. Ignacio de Antioquía).

h) Reconociendo a los bautizados con sus vocaciones peculiares, sus carismas propios, sus funciones y ministerios respectivos. El Sacerdote está llamado a dar cabida tanto en su vida personal como en su actividad pastoral a la iniciativa del Espíritu siempre nuevo y original, siempre creativo y sorprendente, que regala a la comunidad de Jesucristo la insondable riqueza de sus dones. Acoger con gozo los carismas significa tanto como acoger al Espíritu (L. A. Montes Peral). El Concilio (cf. PO 9) atri- 
buye a los presbíteros la tarea de "descubrir, reconocer, coordinar y llevar a la unidad y al fruto debido los carismas del Pueblo de Dios (J. M. Rovira Belloso). "Los carismas no los damos nosotros, los sacerdotes...El sacerdote "descubre" los carismas, que ya se dan en cada comunidad. En cualquier comunidad existen dones y carismas, que son el soporte y la fuente de corresponsabilidad" (Mons. Oliver). Los Sacerdotes han de redescubrir la diversidad de ministerios al servicio de la Iglesia y de su misión, sabiendo que en la Iglesia no todos los miembros tienen la misma función (Rm 12,4). Entre la amplia variedad de los carismas que estructuran la Iglesia (LG 32), el ministerio ordenado desempeña un papel irreemplazable, especialmente como garante y signo de la apostolicidad de toda la Iglesia.

i) Poniendo en marcha las prácticas sinodales (Consejo Pastoral, Junta Económica...), como aportaciones para mejor traducir en la vida de las comunidades una conciencia eclesial más fuerte en los bautizados.

j) Superando aquellas dificultades, como la dispersión geográfica, el cruce de mentalidades diferentes y de intereses opuestos..., que pueden obstaculizar la vivencia de la diocesaneidad mediante la acogida y ayuda fraternas, la hospitalidad, alguna forma de vida común frecuente, la comunicación de bienes, los encuentros presbiterales, la cooperación pastoral, el reconocimiento de los carismas....

\subsection{Relación con el Obispo}

La relación del Presbítero con la Iglesia le pide la comunión jerárquica con su obispo, la comunión fraterna con los otros presbíteros, con los consagrados, con los laicos, con todos.

El Presbítero está unido con el Obispo por vínculos que nacen del sacramento del Orden: "en verdad no se da ministerio sacerdotal sino en la comunión con el Sumo Pontífice y con el Colegio Episcopal, particularmente con el propio Obispo, hacia los cuales debe observarse obediencia y respeto" (PDV 28).

Ser presbítero equivale a ser "necesario" cooperador del Obispo (cf. PO 7) ya que por la unión en la comunión sacramental, el Presbítero es ayuda e instrumento del Orden Episcopal. El presbiterado no es autónomo, es un ministerio de colaboración, sacramental y necesario, con los Obispos. En efecto, el Presbítero realiza su ministerio sacerdotal en obe- 
diencia al Obispo y en comunión jerárquica con él. Por esta obediencia y comunión avanzará el Presbítero en la obediencia y comunión con el designio de Dios sobre él y servirá a los hombres, sus hermanos.

"El párroco debe colaborar con el Obispo y con los otros presbíteros de la diócesis para que los fieles, participando en la comunidad parroquial, se sientan también miembros de la diócesis y de la Iglesia universal (CIC cn.529,2). En su ministerio prolonga la acción del Obispo, del cual hace presente su figura de Padre y Pastor. "Así, pues, ningún presbítero puede cumplir cabalmente su misión aislado y como por su cuenta, sino sólo uniendo sus fuerzas con otros presbíteros, bajo la dirección de los que están al frente de la Iglesia" (PO 7). El diario ejercicio del ministerio pastoral será la ocasión para renovar, en la caridad y en la obediencia, la unión profunda que une al Sacerdote con el Obispo en el único presbiterio, en la comunión afectiva y efectiva de la solicitud eclesial, en la dedicación al cuidado evangélico del Pueblo de Dios (PDV 31) en las concretas condiciones del momento presente.

Los Obispos, por su parte, tienen a los presbíteros "como necesarios colaboradores y consejeros en el ministerio y función de enseñar, de santificar y de apacentar al pueblo de Dios" (PO 7). Además, los Obispos han de abrazar siempre con caridad especial a los sacerdotes, los han de considerar siempre como hijos y amigos, han de estar siempre dispuestos a oírlos y han de preocuparse de su condición espiritual, intelectual y material para que ellos puedan vivir santa y piadosamente y cumplir su ministerio con fidelidad y éxito" (ChD.16).

\subsection{Relación con los Presbiteros}

Todos los presbíteros están unidos entre sí por la íntima fraternidad sacramental y forman un presbiterio especial en la Diócesis a cuyo servicio se consagran bajo el obispo propio" (PO 8). "Cada sacerdote está unido a los demás miembros de este presbiterio, gracias al sacramento del Orden, con vínculos particulares de caridad pastoral, de ministerio y de fraternidad" (PDV 17) al servicio de la obra santificadora de Jesucristo y de la misión de la Iglesia en un lugar determinado. La ordenación nos hace sacramentalmente hermanos.

La razón última de la fraternidad presbiteral es de orden teológico: ser presbítero es formar parte del "Orden Presbiteral". El sacerdote nece- 
sita del Sacerdote para ser sacerdote y para trabajar y vivir como tal. "Cada presbítero no es un ser aislado; está unido a los demás presbíteros, y el principio de esta unidad es su lazo con el Obispo" (Lecuyer).

La vida fraterna es fuente de serenidad, consuelo y alegría en el ejercicio del ministerio pastoral. Para que esta vida fraterna sea una realidad viva es necesario que los Presbíteros estén dispuestos a acompañar muy de cerca de los presbíteros enfermos y ancianos, a los más necesitados de ayuda espiritual y afectiva, material y pastoral, a los que atraviesan dificultades, a los que están necesitados de comprensión y de escucha, a los sacerdotes jóvenes que comienzan la hermosa y difícil tarea de evangelizar y edificar la Iglesia del Señor. Además los Presbíteros han de valorar cada día más la vida en común, la importancia de la oración compartida y la necesidad de programar, revisar y evaluar los proyectos y planes pastorales con otros hermanos sacerdotes, religiosos y laicos.

La fraternidad sacramental de los Presbíteros se traduce también en la disposición para el trabajo pastoral "en equipo". Ahora bien para trabajar en equipo es necesario que los Presbíteros asuman y sepan integrar las diferencias de carácter, de mentalidad, de criterios pastorales. Las dotes personales enriquecen los proyectos y los trabajos comunes. La tarea se perfecciona con un proyecto elaborado y asumido por todos.

La fraternidad de los presbíteros se hace más amplia y abierta cuando busca y promueve la participación de los laicos y de las religiosas en la misión pastoral de la Iglesia.

\subsection{Relación con los Laicos}

Los presbíteros tienen también una relación peculiar con los laicos, a quienes han engendrado espiritualmente por el Bautismo y la Doctrina. Los Presbíteros están de algún modo a la cabeza de la mesa familiar, "ante" los miembros", pero "con" ellos y "al servicio" de todos y cada uno. Presidir no es buscar los propios intereses, sino los de Jesucristo, del cual todos son discípulos, para trabajar juntamente con los fieles laicos, reconociendo y promoviendo su dignidad, respetando asimismo su justa libertad, aceptando gozosamente su experiencia y competencia en los diversos campos de la actividad humana, reconociendo los signos de los tiempos con ellos y descubriendo la variedad de carismas desde los más humildes a los más elevados" (PO 9). 
No se puede plantear la espiritualidad del presbítero sin la relación con los seglares. Esta relación se hace visible de muchas maneras y formas: cercanía a ellos, interés por sus problemas y necesidades, capacidad de acogida y de escucha, oración compartida, programación, realización y revisión pastoral compartidas. Es necesario potenciar la formación de la fe en los laicos utilizando preferentemente el catecumenado de adultos y otras instituciones docentes y educativas de la Diócesis, así como fomentar su específica espiritualidad y misión en la secularidad.

Los Presbíteros han de superar el clericalismo y las desconfianzas que pudieran existir hacia los laicos y han de animarles a que participen desde el don recibido en la vida y misión de la Iglesia. Los cristianos laicos tienen un lugar original e insustituible en la Iglesia (ChFL 58). Ahora bien, "la participación de los laicos en la vida y misión de la Iglesia no puede comprenderse adecuadamente si no se sitúa en el contexto de la Iglesia "misterio de comunión" (CLIM 19).

Recordemos la enseñanza del Concilio Vaticano II: "La Iglesia no está verdaderamente formada, no vive plenamente, no es señal perfecta de Cristo entre los hombres, mientras no exista y trabaje con los Pastores un laicado propiamente dicho. Porque el Evangelio no puede penetrar profundamente en las conciencias, en la vida y en el trabajo de un pueblo sin la presencia activa de los seglares" 14 .

Los Pastores han de ayudar a los laicos a hacerse presentes en la vida pública: el dilatado complejo mundo de la política, de la realidad social, de la economía; así como también de la cultura, de las ciencias y de las artes, de la vida internacional, de los órganos de comunicación social y también de otras realidades particularmente abiertas a la evangelización, como el amor, la familia, la educación de los hijos" (CLIM 45). Han de sentirse en este mundo complejo "Iglesia en el mundo" y han de ser conscientes de que con su participación en la vida pública "hacen presente a la Iglesia en el mundo y animan y transforman la sociedad según el espíritu del Evangelio" ${ }^{15}$.

Además, los Presbíteros han de promover el apostolado individual y el apostolado asociado en los laicos y han de ofrecerles cauces adecuados para su formación permanente integral que es "una prioridad de máxima urgencia para toda la Iglesia" (CLIM 70).

14 Concilio Vaticano II: "Ad Gentes", n.21.

15 Conferencia Episcopal Española: "Cristianos Laicos, Iglesia en el Mundo". 


\subsection{Relación con el Mundo}

La relación del Presbítero con el mundo es una realidad que pertenece a su espiritualidad ya que ésta es de inserción en el mundo y en sus realidades humanas e históricas, si bien no es la misma que la del laico. El Presbítero ha de saber estar en el mundo sin ser mundano.

La inserción del sacerdote en el mundo se debe al hecho de participar de modo especial en la consagración y misión de Cristo, el Verbo Encarnado.

Su vinculación con la Iglesia Particular le empuja a amar la realidad secular que forma parte de la misma y de él mismo y a defender su identidad cultural.

El sacerdote diocesano secular vive en el mundo y su misión se dirige al hombre y a la mujer. Por su condición ciudadana, por su bautismo y por el ministerio del Orden vive una "secularidad" propia y específica. El Sacerdote se manifiesta en el corazón del mundo como transparencia de Cristo, por eso, no se confunde con el mundo.

\section{Las relaciones del Sacerdote y su espiritualidad}

\subsection{Los Sacerdotes, signos de Jesucristo, Sumo y Eterno Sacerdote}

\subsubsection{Jesucristo, sumo y eterno Sacerdote}

Pongámonos en la perspectiva de Dios Padre, Hijo y Espíritu Santo. Dios quiere que todos los hombres se salven y lleguen al conocimiento de la verdad (ITim 2,4). Nos ha enviado a su Hijo Jesucristo como pastor y salvador, convirtiéndolo en el único y definitivo sacerdote de la nueva y eterna alianza (cf. Heb 2,17-18).

El Sacerdocio de Cristo es existencial porque abarca la totalidad de su persona en su obediencia al Padre. Jesús alcanza la perfección (cf. Heb $5,9)$ por sus sufrimientos y su oración, por la oblación, por amor, de su vida (cf. Heb 5,7-10).

Contemplemos a Jesucristo, como el sumo y eterno Sacerdote de la Nueva y Eterna Alianza. La novedad del sacerdocio de Cristo ha de impregnar el estilo de vida de los sacerdotes. 
A) ¿Qué pensó Jesús del Sacerdocio y del culto judío?

Jesús no se designó a sí mismo como sacerdote, no pertenecía a nin-

guna familia sacerdotal ni se relacionó con el sacerdocio cultual-institucional del Judaísmo.

Jesús criticó el comportamiento de los sacerdotes. La parábola del Buen Samaritano (Lc 10,21) rechaza el comportamiento del sacerdote por su falta de sensibilidad humana, por su nulo compromiso ante el que sufre, por su incapacidad de ir más allá de las normas, por su temor a asumir algún riesgo estando en grave peligro la vida de un hombre.

Jesús criticó también el culto que ofrecían los Sacerdotes en el Templo de Jerusalén por su formalismo, su ritualismo, y sus abusos. Habían olvidado que Dios quiere ante todo que el hombre le ofrezca el sacrificio de su corazón, de su vida (cf. Sal 50,18-19) antes que ofrendas de animales, de vegetales... (Jn 4,31).

B) La novedad del sacerdocio de Jesucristo

La Carta a los Hebreos llama a Jesucristo Sacerdote y habla del culto nuevo y del sacrificio de Jesucristo, pero lo hace dándoles un sentido totalmente nuevo en referencia al Judaísmo. Todo queda personalizado en Él: Él es el verdadero templo, el real sumo sacerdote, el altar de los sacrificios, el que presenta la sangre ante el trono de Dios, el que entra en el santuario definitivo, el que ha consumado con su entrega de una vez para siempre a todos los que estaban llamados a la santidad.

a) Cristo, cuando entró en el mundo, dijo: "me has formado un cuerpo... he aquí que vengo a hacer, oh Dios, tu voluntad" (Heb 10,5-7). Toda la vida de Jesús estuvo puesta bajo el signo de la obediencia: "se hizo obediente hasta la muerte, y una muerte de cruz" (Fil 2,6-11).

b) Cristo ha sido nombrado sacerdote por Dios: "Cristo no se apropió la gloria del Sumo Sacerdocio, sino que la tuvo de quien le dijo: "Hijo mío eres tú; yo te he engendrado hoy. Como también dice en el otro lugar: Tú eres sacerdote para siempre, a semejanza de Melquisedec" (Heb 5,5).

c) El sacerdocio de Jesucristo ha comenzado con la Encarnación (Heb 3,17), ha alcanzado su cima en su pasión y muerte en la cruz, y, por la glorificación, ha sido consumado para siempre en la gloria celeste. 
d) Cristo "tuvo que hacerse semejante en todo a sus hermanos (Heb 2,17), excepto en el pecado" (Heb 4,15). No tenía "carne" y se hizo "carne", se metió en nuestra "carne": se encarnó. Jesús "encerró" a Dios en el cerco de nuestra debilidad y flaqueza. En el himno de la Carta a los Filipenses se usa un verbo estremecedor: "se vació a sí mismo". Fue un hombre servidor (PDV 21). Tomó la condición de esclavo, se humilló voluntariamente, bajo hasta la sima de un condenado vil porque obedeció hasta morir. "Él es el Hijo, y en cuanto hecho partícipe por su carne y sangre del destino de sus hermanos constituido pontífice a su favor" (O. G. de Cardedal). Esto es una novedad.

La necesidad de la asimilación a los hombres en vistas del sacerdocio resulta de la misión asumida por Cristo: "porque se ocupa de la descendencia de Abraham" (Heb 2,16) para abrir a todo hombre el camino de la salvación y de la gloria, "por eso tuvo que asemejarse...".

Esta "asimilación" se extiende, según el contexto, a todos los ámbitos del ser humano, incluidos los aspectos más dramáticos y dolorosos de la existencia humana: las tentaciones, los sufrimientos y la muerte. Esta condición era sorprendente y extraña ya que no correspondía ni a la tradición del Antiguo Testamento que hablaba de separación, ni a las costumbres de aquel tiempo que ponían de relieve la ambición.

Esta "asimilación a los humanos" excluye el pecado $(\mathrm{Heb} 4,15)$. De este modo, se distinguen la prueba y la falta, la tentación y el pecado. Jesús fue tentado, pero no pecó. Cristo es un sumo sacerdote "santo, inocente, inmaculado" (Heb 7,26), "que se ofreció a Dios como una víctima sin mancha" (Heb 9,14). Esta ausencia de pecado no destruye su solidaridad con los humanos ya que la auténtica solidaridad con los pecadores no consiste en hacerse pecador como ellos y con ellos, sino en cargar con ellos todo el peso de la pena que resulta de ellos: Jesús, el santo, "ha cargado con los pecados de la multitud" (Heb 9,28), no avergonzándose de "llamarlos hermanos" (Heb 2,11).

e) Jesús se hace semejante a nosotros, "a fin de llegar a ser sumo sacerdote misericordioso y digno de fe" (Heb 2,17).

Jesús es Sacerdote "misericordioso" (cf. Heb 4,15-16). Jesús es el Sacerdote acreditado por Dios y elevado a la derecha de Dios. Jesús es también el sacerdote misericordioso. La misericordia y la ayuda que recibimos son favores gratuitos, que nos vienen de la misericordia divina; pero al mismo tiempo tienen una expresión y base muy humanas: nos vie- 
nen por la compasión de Jesús, fundamentada sobre la experiencia directa de todas nuestras pruebas (A. Vanhoye). Cristo es capaz de compadecerse de nosotros, de tener misericordia de todos los humanos, de interceder por todos ante Dios (Heb 7,25) porque ha sido probado en el sufrimiento (Heb 2,18). Por eso, "acerquémonos confiadamente al trono de gracia, a fin de alcanzar misericordia y hallar gracia para ser socorridos en el tiempo oportuno" (Heb 4,16).

Jesús es Sacerdote "fiel a Dios Padre" o "digno de fe o confianza" dado que Dios lo ha acreditado. El autor invita a los creyentes a contemplar a Cristo glorioso entronizado al lado de Dios y por tanto plenamente "digno de fe"; por eso merece nuestra confianza.

La predicación profética de Jesús, refrendada por los milagros, tuvo su momento culminante en el misterio pascual, suprema palabra del amor divino con que el Padre nos habló.

f) Jesús es sacerdote y víctima. La muerte de Jesús en la cruz es la consecuencia el resultado de su vida entera, de su anuncio y de su acción. Jesús había actuado con tal autoridad, había hablado con tal libertad, había denunciado los pecados con tal claridad y había manifestado unas pretensiones de tal categoría que llamó poderosamente la atención de la gente y provoco incomprensiones, críticas, insultos, persecución... y finalmente la muerte.

Jesús no buscó la muerte, sino que la vio venir sobre Él desde fuera, la aceptó, se mantuvo fiel al Padre, a sí mismo y a su misión, y le dio un sentido salvador (Mt 26,28; Lc 22,19; cf. Mc 10,45): Cristo murió por nuestros pecados (cf. ICor 15,3-5). Hay una perfecta identidad entre el sacerdote que ofrece y la víctima que es ofrecida. Es una novedad.

El sacrificio que ofrece Jesús a Dios es un sacrificio personal, existencial, no un sacrificio ritual. Cristo se ofrece a sí mismo. Él es la "víctima sacrificial". Cristo se ofrece al Padre voluntariamente: "la entrega voluntaria caracteriza la pasión de Jesús".

En la cruz, de modo especial, Jesús se demuestra a sí mismo el Buen Pastor que da la vida por las ovejas para congregarlas en esa unidad que tiene en Él su consistencia (Sínodo, 1971, 1). El sacerdocio de Cristo incluye la función profética y real del Verbo de Dios, encarnado.

g) Jesús se ofrece al Padre por el Espíritu eterno (Heb 9,14). No es suficiente tener una víctima digna de ser ofrecida a Dios; se requiere también que haya un sacerdote capaz de ofrecer y hacer llegar esa víctima a 
Dios. Jesús es ese Sacerdote porque posee el "Espíritu eterno que le da, si se puede hablar así, la fuerza ascensional necesaria para elevarse hasta Dios, es decir, la fuerza del amor sin la menor sombra de egoísmo" 16.

h) Cristo, aun siendo Hijo, con lo que padeció experimentó la obediencia (Heb 5,8).

i) El camino sacerdotal de Jesús para llegar a la perfección y ser entronizado como sumo sacerdote salvador es un camino de humildad, no de ambiciones; de servicio, no de poder; de entrega, no de autoglorificación; de educación dolorosa: "y aun siendo Hijo, con lo que padeció experimentó la obediencia" (Heb 5,7-8), no de vanagloria (Fil 2,6-11), de "debilidad asumida".

j) Jesús oró "en el dolor, en la agonía y en la cruz" (cf. Mc 14,33-36; 15,34; Lc 23,46). La Pasión, asumida y vivida en la oración, se convierte en ofrenda al Padre. La oración de Jesús es escuchada por Dios a causa de su profundo respeto hacia Dios que le concedió la fuerza necesaria para superar la angustia, afrontar la muerte sin temblar y transformar su sufrimiento en camino de salvación. Y fue escuchada por el Padre resucitándolo de entre los muertos: Dios no lo abandona en la muerte; Dios lo resucita.

k) En su oración Jesús experimentó a Dios como su “Abba”. Esto significa que vivenció a Dios como:

- su Padre en quien confía y descansa últimamente su corazón: "no se haga mi voluntad, sino la tuya"; "Padre, a tus manos encomiendo mi espíritu”. Jesús se eleva hacia la comunión total con la voluntad de su Padre.

- un Dios que no se deja llevar por supuestas iras o venganzas...ni como un Dios que exija sacrificios para aplacar su supuesta cólera, sino como un Dios clemente y compasivo que "nos ama tanto que nos ha entregado a su propio Hijo para que todo el que cree en él no perezca sino que tenga vida eterna" (cf. Jn 3,16).

- como un Padre que no desprecia a los pecadores, publicanos... sino que los acoge, los perdona: "En Cristo se ha manifestado la bondad de Dios para la humanidad".

${ }^{16}$ Albert Vanhoye: "Prêtres anciens, prêtre nouveau selon le Nouveau Testament", p.224; Edit. du Seuil, París,1980. 
- como un Dios crucificado y sufriente, impotente y débil, que se nos muestra en la Cruz reconciliando al hombre consigo (IICor 5,19-20).

1) La resurrección y exaltación de Jesús. El Padre no abandonó a su Hijo en la muerte, sino que lo resucitó, acreditándolo. Por la resurrección Dios corrige la negatividad inherente a la muerte de Jesús, el Justo sufriente, y lleva su vida a su consumación plena y a su plenificación total en Dios. Con la resurrección de Jesús se nos desvela que en Cristo crucificado estaba Dios compartiendo nuestra vida y salvándonos (cf. IICor $5,19)$. La resurrección es la confirmación de la verdad de la vida, de la causa y de la persona de Jesús. Por haber sufrido la muerte, Jesús ha sido coronado de gloria y honor" (Heb 2,9) y "ha sido exaltado por Dios que le ha dado un "Nombre-sobre-todo-nombre (Fil 2,6-9) ante el cual toda rodilla debe doblarse en adoración.

La resurrección de Jesús es buena noticia para la humanidad entera: Dios no abandona en la cuneta de la historia a quienes han entregado su vida por su Reino. La resurrección de Cristo genera en la humanidad la esperanza escatológica cuya meta final es la resurrección de los muertos y la recreación de todas las cosas en Jesucristo.

11) El sacerdocio de Cristo perdura en el cielo; es un sacerdocio celeste: "...éste posee un sacerdocio perfecto porque permanece para siempre" (Heb 7,24). El sacrificio de Cristo no puede ser repetido ya que por la resurrección su oblación y su entrega han quedado perennizadas para siempre.

m) El poder salvador del Sumo Sacerdote. Jesús nos ha alcanzado el perdón de los pecados y nos ha unido para siempre a Dios: "Y, llegado a la perfección, se convirtió en causa de salvación eterna para todos los que le obedecen" (Heb 5,9); "hemos sido santificados por la ofrenda del cuerpo de Jesucristo, una vez por todas" (Heb 10,10). "Con una sola oblación perfeccionó para siempre a los santificados" (Heb 10,14). Es una novedad.

\subsubsection{El Sacerdote ministerial participa del Sacerdocio de Cristo}

Teniendo en cuenta que Cristo es el único Sacerdote, el Sacrificio definitivo, el Mediador único, la única Salvación, todo otro sacerdocio -el de la Nueva Alianza- no es más que una participación en ese único sacerdocio de Jesucristo. 
El sacerdocio común o bautismal de los cristianos, como participación real en el sacerdocio de Cristo, constituye una propiedad esencial del Nuevo Pueblo de Dios (LG 10-11), y es consecuencia de que el pueblo cristiano ha sido elegido por Dios como puente con la humanidad y pertenece a todo creyente en cuanto injertado en este pueblo. Se funda en el carácter bautismal. Gracias al sacerdocio ministerial, los fieles son conscientes de su sacerdocio común y lo actualizan, ya que el sacerdote les recuerda que son pueblo de Dios y los capacita para ofrecer sacrificios espirituales mediante los cuales Cristo mismo hace de nosotros un don eterno al Padre.

El Sacerdocio ministerial es fruto de una elección, de una vocación específica (cf. Lc 6,13). En el seno del Pueblo Sacerdotal, el Señor ha instituido un sacerdocio ministerial, al cual son llamados algunos fieles para servir, por medio de la sagrada potestad, a todos los demás con caridad pastoral. Este sacerdocio se funda en el carácter impreso por el sacramento del Orden que configura a Cristo Sacerdote y le permite, con sagrada potestad, actuar en la persona de Cristo Cabeza para ofrecer el Sacrificio y para perdonar los pecados (PO 2; ChD.15). A los bautizados que han recibido en un segundo momento el don del sacerdocio ministerial, les es conferida sacramentalmente una nueva y específica misión: impersonar en el seno del Pueblo de Dios la triple función -profética, cultual y realdel mismo Cristo, en cuanto Cabeza y Pastor de la Iglesia (PDV nn.1315). Por eso nuestro sacerdocio es "jerárquico" y "ministerial".

La identidad del sacerdote deriva de la participación específica en el Sacerdocio de Cristo, por lo que el ordenado se transforma -en la Iglesia y para la Iglesia- en imagen real, viva y trasparente de Cristo Sacerdote (PDV 15). La función del ministerio sacerdotal no es otra que manifestar visiblemente la presencia de Cristo Mediador y su acción en la vida de la Iglesia (cf. Catecismo, n. 1545). El sentido de la representación del ministro en la comunidad no es "el hacer las veces de Cristo", ni "el de suplir" su presencia. La representación en el orden del signo sacramental indica presencia significante y activa, manteniendo la necesaria distinción entre representante y representado (E. Royón).

Por su poder de ofrecer el Sacrificio del Cuerpo y de la Sangre de Cristo, por su potestad de anunciar con autoridad el Evangelio, de vencer el mal del pecado mediante el perdón sacramental, él -en persona de Cristo Cabeza- es fuente de vida y de vitalidad en la Iglesia y en la parroquia. 
El sacerdote no es la fuente de esta vida espiritual, sino el hombre que la distribuye a todo el pueblo de Dios. Es el siervo que, con la unción del Espíritu, accede al santuario sacramental: Cristo Crucificado (cf. Jn 19,31-37) y Resucitado (cf. Jn 20,20-23), del cual mana la salvación (Cong. del Clero,d.c.,n.8).

\subsubsection{La espiritualidad del Sacerdote a la luz de Cristo, Sumo y Eterno Sacerdote}

La configuración con Cristo abarca una dimensión subjetiva de respuesta personal a vivir conforme al estilo de Jesús y que se concreta en el seguimiento de Jesús en su radicalidad evangélica y, a la vez, un aspecto objetivo de signo sacramental para la comunidad, es decir, "el sacerdote hace sacramentalmente presente a Cristo, Salvador de todo hombre, entre los hermanos" (Sínodo 1971).

Ser signos de Cristo sumo y eterno Sacerdote, "ser instrumento vivo de Cristo Sacerdote" (PO 12), ser "servidor de Cristo Maestro, Sacerdote y Rey" (PO 1) para servir fielmente a la Iglesia ( PO 14) implica una espiritualidad peculiar según la imagen del sumo y eterno Sacerdote. Viviendo la espiritualidad sacerdotal, el sacerdote ministro se hace signo creíble del Buen Pastor en un mundo que pide autenticidad, en una Iglesia-sacramento y en una nueva etapa de evangelización.

Los rasgos de esta espiritualidad son los siguientes:

A) El Sacerdote ha sido llamado por Dios de entre los hombres bautizados y puesto a favor de los hombres en lo que se refiere a Dios (Heb.5,1.4), en una comunidad eclesial concreta. Elegidos pero no separados de sus hermanos. El Sacerdote ha de agradecer siempre el don de la llamada de Dios y ha de vivir su condición de discípulo de Jesús haciendo suya la "forma de vida apostólica": encuentro con el Señor, seguimiento de Cristo, desprendimiento, fraternidad, servicio a la misión.

B) El Sacerdote ha sido consagrado por la Unción del Espíritu Santo para representar a Cristo ante la Comunidad Cristiana. Queda así constituido en instrumento vivo de Cristo y participa de su autoridad como un servicio para la edificación de la Iglesia. La ordenación es vista como una consagración del ministro al misterio al que sirve, en todo su ser y para siempre. 
C) "El cristiano llamado al ministerio sacerdotal no recibe por la ordenación una función puramente exterior, sino más bien una participación original del sacerdocio de Cristo, en virtud de la cual él representa a Cristo a la cabeza de la Comunidad y como de cara a ella. Así, pues, el ministerio es una manera específica de vivir al servicio cristiano dentro de la Iglesia. Esta especificidad aparece más claramente en la función de presidir la Eucaristía, presidencia necesaria para la plena realidad del culto cristiano. La proclamación de la Palabra y la carga pastoral se ordenan hacia la Eucaristía, que consagra toda la existencia cristiana en el mundo" ${ }^{17}$.

D) El Sacerdote por la acción del Espíritu está llamado y es ungido a identificarse con Cristo, Hijo de Dios. Por ello hará suyo el camino del Señor que se caracteriza así:

a) Un camino de asemejarse a los hombres en todo, menos en el pecado.

La espiritualidad del Presbítero no es desencarnada ni a-histórica, sino encarnada y a favor de los hombres (cf. PO 1,3-4), pues ha de encarnarse según lo hizo Jesús (cf. GS 22). El Presbítero no ha de vivir separado del mundo sino estar en el "corazón del mundo", no para participar en el pecado del mundo, sino para ser testigo de Dios y de los valores del Reino en este mundo.

La encarnación del Presbítero es "costoso abajamiento, descubrimiento gozoso y decisión de beber de ese pozo de agua que está en el abajo de la historia" (I. Sobrino), renuncia expresa a las mediaciones de poder y solidaridad con los empobrecidos de este mundo y se hace visible en estas actitudes y signos:

La opción preferencial, ni excluyente ni exclusiva (Juan Pablo II), por los pobres, por los necesitados, por los desvalidos, por los que no cuentan, por los pecadores. Por ello, asumirán con objetividad y serán fieles a la realidad; se dejarán impactar por el mundo de los necesitados; proclamarán y defenderán los derechos humanos; compartirán la condición de los pobres para ayudarles en su liberación integral y denunciarán los pecados y estructuras injustas. Se deben a todos, pero se le han encomendado de modo particular los pobres y los débiles.

17 Comisión Teológica Internacional: “El Sacerdocio ministerial ” 1971). 
La experiencia humana del dolor en sus múltiples manifestaciones: indigencia y enfermedad, marginación e ignorancia, soledad y pobrezas materiales y morales". Desde esta experiencia, el sacerdote "enriquece su propia humanidad y la hace más auténtica y transparente en un creciente y apasionante amor al hombre" (PDV 72).

La exclusión del pecado. Ha de hacerse semejante en todo a los hombres, sus hermanos, excepto en el pecado (Heb 5,14). Teniendo en cuenta que "la presencia de Cristo en el ministro no debe ser entendida como si éste estuviese exento de todas las flaquezas humanas, del afán de poder, de errores, es decir, del pecado" ${ }^{18}$. El Sacerdote ha de estar en un proceso constante de conversión y de renovación. También a los Presbíteros el Señor les dice: "arrepentíos y convertíos que el reino de Dios está cerca" (Mc 1,14).

b) Un camino de oración

El Sacerdote ha de estar en sintonía con el Dios que se revela en la pasión y en la cruz de Jesús. La oración es el lugar peculiar para alcanzar la sintonía con el Dios que nos ha revelado Jesús. Por eso debe ser una persona orante:

- en la soledad para acrisolar su fidelidad al Padre, rechazar las tentaciones mesiánicas y ofrecer las lágrimas y esperanzas de los hombres y para proseguir la tarea evangelizadora;

- en el camino del servicio pastoral para que se transforme su acción pastoral en alabanza al Padre por Cristo en el Espíritu Santo y en servicio a la humanidad;

- en las tribulaciones por el Evangelio para "conformar su voluntad con la del Padre.

c) Un camino de compasión y misericordia

El Sacerdote, desde la contemplación de Jesucristo, ha de ser compasivo y misericordioso, ofreciendo unos signos que muestran el rostro del Sumo Sacerdote compasivo, misericordioso y digno de fe. El sacerdote "puede sentir compasión hacia los ignorantes y extraviados, por estar también él envuelto en flaqueza" (Heb 5,2).

18 Catecismo de la Iglesia Católica, n.1550. 
Las actitudes del hombre del Reino son, entre otras, la misericordia como traducción del "misereor super turbas" de Jesús, la indignación que produce en todo hombre de buena voluntad el sufrimiento y la opresión y que lleva a la denuncia, el gozo de anunciar el reino que es buena noticia para todos, especialmente para los pobres y la alegría que produce el gozo de los pobres cuando la oyen, la entienden y la celebran.

Estas actitudes fundamentales dan un nuevo rostro a nuestra espiritualidad ya que nos llevan a celebrar la fe con los demás evitando así que aparezcamos como personas extrañas y ajenas al mundo real y a las personas.

Los signos de este camino de misericordia son:

- La confianza en Dios Padre que nos ama, que se acuerda del hombre y nunca se olvida de él; que sale a nuestro encuentro en la inmensa pobreza de nuestros pecados y nos acoge y nos perdona;

- la misericordia entrañable y no la venganza; el perdón y no el rencor; la acogida y no el rechazo. Es la espiritualidad del Buen Samaritano que, conmovido ante el sufrimiento de un hombre, "derramó sobre sus heridas el aceite, las vendó, "cargó con él, se encargó de él";

- la ofrenda y entrega de su propia persona y no el egoísmo. Es la espiritualidad del Siervo de Yahvé que da su vida por la multitud: "en sus llagas hemos sido curados";

- la acogida de los pecadores y el perdón inmerecido que les regala como lo hizo Jesús que "se compadece de nuestras flaquezas, debilidades y perdona nuestros pecados";

- el culto que supone el respeto al derecho y a la justicia, siguiendo las enseñanzas de Jesús que manifiesta: "misericordia quiero y no sacrificios" (Os 6,6).

d) Un camino profético

El Espíritu ungió a Jesús para anunciar la Buena Noticia a los pobres...(cf. Lc 4,16ss). El Sacerdote también ha sido ungido por el Espíritu que lo ha hecho testigo y profeta, y lo espolea a ofrecer un servicio profético desde la contemplación y por medio del testimonio de su vida y el anuncio del Evangelio.

"El Señor nos ayudará a decir cosas que sean verdaderas, en vez de decir cosas que sean sólo nuestras. Pues, si sólo dijésemos las nuestras, seríamos pastores que nos estaríamos apacentando a nosotros mismos, y 
no a las ovejas; en cambio, si lo que decimos es suyo, Él es quien apacienta, sea por medio de quien sea" (San Agustín).

¿Dónde están los profetas? En el Antiguo Testamento se añoraban los profetas, sobre todo, en los momentos cruciales de la vida del Pueblo de Dios. ¿También se añoran los profetas en nuestros días? Hacen falta los profetas. Da la impresión de que el bienestar, el honor, el poder... apagan la voz de los profetas... De todos modos siguen resonando voces que nos alertan para no caer en la trampa de la ideología que, solapadamente, intenta compaginar lo que, desde Jesús y su Reino, es incompatible, servir a dos señores.

¿Qué es un profeta? El profeta "empatiza" con Dios a quien escucha y con el pueblo al que se dirige, está inmerso en la vida del pueblo y hace una lectura creyente de los acontecimientos de la vida de este pueblo. El profeta es capaz de descubrir la voluntad de Dios en los acontecimientos de la historia y puede llenar el presente de esperanza para abrir caminos en el futuro. El profeta, impulsado por el Espíritu de Dios, defiende el plan de Dios ante quienes, apegados a proyectos mundanos, quieren justificarlos ante Dios y ante los hombres.

El profeta ha de ser la voz que, en el horizonte del Reino, denuncia el pecado, la injusticia, la mentira y la hipocresía y que anuncia la Buena Noticia de la Gracia "hasta que Él vuelva". Al mismo tiempo, ha de ser voz de los que no la tienen y ha de relativizar todo logro histórico midiéndolo siempre en referencia al Reino de Dios en plenitud y ha de señalar los senderos que conducen hacia la utopía cristiana, "los nuevos cielos y la nueva tierra", que de alguna manera se va "historizando" en este mundo en espera de su plenificación total en la Casa del Padre.

El profeta ha de rechazar todo lo que destruye la vida y contradice la condición de hijos de Dios en Cristo, venga de donde viniere el ataque o la destrucción de la vida. El Profeta debe ser insobornable en la defensa de la vida y ha de denunciar a quienes la violentan o la destruyen. Defendamos la vida humana desde el seno materno hasta el final que sólo Dios puede definir.

El Profeta defiende los derechos de los pobres y excluidos, su causa es la suya y sus luchas son las suyas, sus desvelos son parte de los suyos.

¿Cuáles son los lugares proféticos donde como comunidad podemos desarrollar la opción profética? 
La espiritualidad que brota del servicio profético se caracteriza por la fortaleza (la parresía) para predicar y dar testimonio de Jesucristo y de su Evangelio ante poderes hostiles, para aproximarnos a Dios con confianza, para mantener la paciencia porque Cristo ha vencido la muerte. Esta "fortaleza" nada tiene que ver con la arrogancia ni la demagogia.

Con la firme certeza de que el Espíritu Santo continúa en medio de nosotros, sigamos caminando para ser los profetas que este tiempo necesita. Continuemos dando al pueblo santo que clama, las esperanzas para vivir y las fuerza para seguir caminando.

¿Cómo ser profetas de esperanza en un mundo donde tanta muerte se produce?

En nuestro tiempo, ser y actuar de profeta conlleva riesgos, temores, persecuciones, cárceles y martirio. Cuando esto suceda: "alégrense, se acerca el reino de Dios" (Mt 5,12). ¿Qué más queremos? ¿qué más podemos esperar? El Espíritu Santo nos da la capacidad de aceptar la persecución y la muerte por el Evangelio anunciado.

e) Un camino de santidad

La santidad de vida: "sería un contrasentido contentarse con una vida mediocre, vivir según una óptica minimalista y una religiosidad superficial" ${ }^{19}$. La santidad ha sido siempre la mejor respuesta de la Iglesia a los tiempos difíciles. Esforcémonos un poco más en vivir santamente, convencidos de lo que el Papa llama "el alto grado de la vida cristiana ordinaria". El Sacerdote está llamado a ser santo por lo que es sacramentalmente (PO 12; LG 32). El Sacerdote ha de ser luz para iluminar, ha de acercarse a Dios para acercar los hombres a Dios, ha de vivir las bienaventuranzas para enseñar a vivirlas a los demás desde su experiencia.

La Iglesia necesita nuevos santos para evangelizar el mundo de hoy; necesita sacerdotes que prediquen la Palabra aprendida del Espíritu, que administren los sacramentos desde una íntima unión con Cristo y guíen a la comunidad cristiana desvelando y actualizando el misterio del amor de Dios. La nueva evangelización pide nuevos evangelizadores, sacerdotes comprometidos con hacer de su sacerdocio un camino hacia la santidad (J. M. Imizcoz).

19 Juan Pablo II: "Novo Millenio Ineunte", 31. 
f) Un camino de humildad, de sencillez y obediencia

Jesús rechazó las tentaciones mesiánicas y escogió el camino de la sencillez, de la entrega para realizar la misión que el Padre le confío. Jesús no hacía milagros para confundir a los fariseos ni para mostrarse más poderoso que los demás, sino para salvar y liberar a los enfermos, a los hambrientos... El perdón de los pecados que regalaba, las comidas que compartía con los pecadores eran signo y clamor del Reinado de Dios que había llegado en Él y con Él como gracia y salvación al mundo para el bien de todos.

Como Jesús, el Sacerdote ha de escoger el camino de sencillez y de humildad. En este sentido rechazará las tentaciones mesiánicas que le sugieren utilizar el poder, el dinero, la sabiduría de este mundo para realizar su misión, y escogerá los medios pobres. El Sacerdote ha de tener una actitud permanente de servicio sin privilegios ni ventajas humanas (cf. PO 1,13; LG 24). Como Jesús ha de pasar por la vida como "uno de tantos", y ha de optar por ser servidor, obediente....

En el Cenáculo de Jerusalén, antes de cenar con sus amigos, Jesús se levanta de la mesa, y se pone a lavar los pies a sus discípulos y les dice: “ si Yo que soy vuestro Maestro os he lavado los pies, haced vosotros lo mismo unos con otros". Es un gesto de amor y de humildad, de entrega y desinterés, que explica de alguna manera el misterio de la Cena de Jesús. ¿Lavamos los pies a nuestros hermanos? El Presbítero debe realizar la autoridad recibida " según el modelo de Cristo, que por amor se hizo el último y el servidor de todos" (Mc 10,43-45; IPed 5,3).

Ayudado y sostenido por la fuerza del Espíritu Santo, se identificará con Cristo, Hijo de Dios, en su confianza, en su obediencia y en su identificación con la voluntad del Padre que quiere que todos se salven y lleguen al conocimiento de la verdad.

g) Un camino eucarístico: presencia y entrega

Gracias a la Encarnación es posible la Eucaristía "donde está el Cuerpo que fue concebido por el Espíritu Santo" 20 y "así hay semejanza entre la santa encarnación y este sacro misterio" ${ }^{21}$.

${ }^{20}$ San Juan de Ávila: "Carta 122".

${ }^{21}$ San Juan de Ávila: "Carta 122". 
Jesús tomó en sus manos un trozo de pan y dice: "esto es mi cuerpo que se entrega por vosotros", y después tomó una copa llena de vino y dice: "este es el cáliz de mi sangre que será derramada por vosotros". "Haced esto en memoria mía".

El Sacerdote ha de cultivar, desarrollar y manifestar las actitudes íntimas que la Eucaristía fomenta 22.

La experiencia del Cenáculo pide al Sacerdote estar en una actitud permanente de purificación y de renovación, como expresión del "ya sî" pero "todavía no" entre los que se mueve y se celebra el banquete eucarístico.

h) Un camino de persecución y de cruz por el Reino de Dios

La espiritualidad del Presbítero es una espiritualidad de un amor encarnado y vivido en el amor solidario con los crucificados de la historia. Esto significa que su espiritualidad es martirial, confesante... La espiritualidad del Sacerdote incluye el martirio.

El Sacerdote, como Jesús, experimentará conflictividad, incomprensión...en su vida porque encarnar en sí mismo y anunciar la palabra y la forma de vida de Jesús es, por una parte, una buena noticia de gracia y de salvación y, por otra, una denuncia de los pecados. Sabemos que cuando se denuncian los pecados, la injusticia, la violencia, la mentira... surge la persecución.

El Sacerdote que se encarna en una realidad transida de "anti-reino" ha de contar con la posibilidad de ser perseguido y crucificado. Cuando se asume la causa de los empobrecidos de este mundo, hay que tener a la vista la posibilidad de la persecución y del martirio.

El Sacerdote que ama a sus hermanos, como Jesús los amó, ha de contar con la cruz en la diversidad de sus formas y rostros concretos: marginación, insulto, descalificación, persecución, cárcel, martirio (cf. Jn $15,20)^{23}$. Estos sufrimientos no deben llevar al Presbítero a la desespe-

22 Juan Pablo II presenta las actitudes eucarísticas del Sacerdote: "la gratitud por los bienes recibidos del cielo, ya que la Eucaristía significa acción de gracias; la presencia sencilla y fraterna, la actitud donante que los lleve a unir su entrega personal al ofrecimiento eucarístico de Cristo; la caridad alimentada por un sacramento que es signo de unidad y de participación; el deseo de contemplación y adoración ante Cristo realmente presente bajo las especies sacramentales" (PDV 48).

23 Marcelino Legido: "El camino apostólico es un camino martirial. En medio de la fraternidad y en medio del mundo espera a los apóstoles el dolor y la muerte, para que dejen transparentar en su cuerpo mortal la fuerza de la gracia del Resucitado que se desborda a los herma- 
ranza: "Vosotros tendréis tribulaciones en este mundo, pero tened confianza: yo he vencido al mundo" (Jn 16,33). De la cruz brotan la vida y la resurrección.

De la Cruz surge una espiritualidad que no puede entenderse al margen del seguimiento del Crucificado, que hoy incluye asumir la causa de los nuevos crucificados por el pecado del mundo. Desde esta vinculación, la Cruz, abierta a la resurrección, se convierte en manantial de esperanza. "Jesús, en la cruz, convierte la muerte en vida, la tristeza en alegría, la servidumbre en libertad, las tinieblas en luz, la división en unidad, la violencia en paz y la desesperación en esperanza. La cruz de Jesús no anuló los tiempos difíciles y conflictivos, ni los hizo fáciles o llevaderos. Simplemente los convirtió en gracia y esperanza: "cuando yo sea levantado de la tierra, atraeré a todos hacia mî” (Jn 12,32) (G. M. Nápole).

\section{i) Un camino de resurrección en Cristo}

El Presbítero ha muerto con Cristo al pecado y con Él ha resucitado místicamente con la esperanza de resucitar un día para la Vida Eterna. Ha de ser testigo ante la humanidad de la resurrección y de la vida eterna y ha de vivir como resucitado, es decir, despojado de las obras del hombre viejo y realizando las obras del hombre nuevo que presenta San Pablo. Porque habéis resucitado con Cristo, vivid en Dios y no en el pecado.

El Presbítero que arriesga su vida por el Evangelio y por los hombres ve en el horizonte de su historia la persecución, la cruz y la muerte. Ahora bien, San Pedro nos dice que "Dios resucitó a Jesús y lo acreditó", le dio la razón. Esto hará Dios con aquel que haya entregado su vida por el Señor y. por los demás: no se perderá en el vacío y en la nada. Dios lo resucitará para la vida eterna y lo guardará para toda la eternidad. Esta es nuestra certeza y nuestra convicción que nacen de la fe. Por eso, el mal, la injusticia, la muerte...no tienen la última palabra sobre la historia de nadie, ya que han sido despojados de su fuerza absoluta por Cristo.

El Sacerdote, por tanto, ha de tener en su vida y en su ministerio un talante de resucitado que se caracteriza por la esperanza y no la desespe-

nos y al universo en la gratuidad para la gratitud. No es el siervo mayor que su Señor. Él ha sido herido; también lo tenemos que ser nosotros. Pero al ser heridos en nuestro cuerpo, avanzamos proclamando el Evangelio. Las heridas de nuestro cuerpo son proclamación del Evangelio" ("Espiritualidad del seguimiento de Jesús según el modelo apostólico", en "Espiritualidad Sacerdotal", Congreso, Comisión Episcopal del Clero, pp. 219-220). 
ranza, la libertad y no la esclavitud, el gozo y no la tristeza, la vida y no la muerte, la paz y no la violencia, el amor y no el odio. Ha de ser inconformista ante la injusticia, inquieto ante los que sufren, utópico ante "el pensamiento único" porque cree en una humanidad fraterna y solidaria y trabaja por ella.

(Continuará) 